\title{
Teaching implications in the pedagogical training of a technical school
}

\author{
Implicações docentes na formação pedagógica de uma escola técnica \\ Implicaciones docentes en la formación pedagógica de una escuela técnica
}

'Universidade Federal Fluminense. Niterói, Rio de Janeiro, Brazil.

How to cite this article:

Leite ICM, Mourão LC, Almeida ACV. Teaching implications in the pedagogical training of a technical school. Rev Bras Enferm. 2020;73(3):e20180679. doi: http://dx.doi.org/10.1590/0034-7167-2018-0679

Corresponding author:

Isabel Cristina de Moura Leite

E-mail: isabelcristinademouraleite@gmail.com

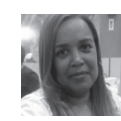

EDITOR IN CHIEF: Antonio José de Almeida Filho ASSOCIATE EDITOR: Hugo Fernandes

Submission: 08-30-2018 Approval: 04-16-2019

\begin{abstract}
Objective: to analyze the teaching implications with the pedagogical training in a Technical School of SUS. Method: a qualitative study that has the Institutional Analysis as theoretical and methodological framework, Institutional Socio-Clinical modality, whose data were collected from July 2017 to August 2018, with 07 health professionals. Results: they were presented from two themes: implications of teachers with training: the old Technical School New directions are evidenced in the implied behavior of teachers: a new Technical School? Final considerations: knowing the factors that hinder and facilitate the pedagogical training in health, and especially to clarify how the behaviors instituted opened loopholes for instituting movements present in that setting, revealing the nuances of a new institutionalization, contributed to the collective construction of strategies related to the training of new teachers. Descriptors: Nursing Education; Health Human Resources Training; Nursing; Nursing Faculty Practice; Unified Health System
\end{abstract}

\section{RESUMO}

Objetivo: analisar as implicações docentes com a formação pedagógica em uma Escola Técnica do SUS. Método: estudo qualitativo que tem como referencial teórico e metodológico, a Análise Institucional na modalidade Socioclínica Institucional, cujos dados foram coletados no período de julho de 2017 a agosto de 2018, com 07 profissionais de saúde. Resultados: foram apresentados a partir de duas temáticas: implicações dos docentes com o processo de formação: a antiga Escola Técnica; Novos rumos são evidenciados no comportamento implicado dos docentes: uma nova Escola Técnica? Considerações finais: conhecer os fatores que dificultam e facilitam o processo de formação pedagógica em Saúde e, principalmente, esclarecer como os comportamentos instituídos abriram brechas para movimentos instituintes presentes naquele cenário, revelando as nuances de uma nova institucionalização, contribuiu para a construção coletiva de estratégias relacionadas à formação de novos docentes.

Descritores: Educação em Enfermagem; Formação Profissional em Saúde; Enfermagem; Prática do Docente de Enfermagem; Sistema Único de Saúde.

\section{RESUMEN}

Objetivo: analizar las implicaciones docentes con la formación pedagógica en una Escuela Técnica del SUS. Método: el estudio cualitativo, que tiene como referencial teórico y metodológico el Análisis Institucional en la modalidad Socioclínica Institucional, cuyos datos fueron recolectados en el período de julio de 2017 a agosto de 2018, con 07 profesionales de salud. Resultados: se presentaron a partir de las temáticas: las implicaciones de los docentes con el proceso de formación: la antigua Escuela Técnica; Los nuevos rumbos son evidenciados en el comportamiento implicado de los docentes: una nueva Escuela Técnica? Consideraciones finales: conocer los factores que dificultan y facilitan el proceso de formación pedagógica en Salud, y principalmente aclarar cómo los comportamientos instituidos abrieron brechas para movimientos instituyentes presentes en aquel escenario, revelando los matices de una nueva institucionalización, contribuyó a la construcción colectiva de estrategias relacionadas a la formación de nuevos docentes.

Descriptores: Educación en Enfermería; Formación Profesional en Salud; Enfermería; Práctica del Docente de Enfermería; Sistema Único de Salud. 


\section{INTRODUCTION}

Nursing education in Brazil underwent changes, following the Diretrizes Curriculares Nacionais do Curso de Graduação em Enfermagem (freely translated as Undergraduate Nursing Course Brazilian Curricular Guidelines), which reinforce the need for articulation with the Brazilian Unified Health System (SUS - Sistema Único de Saúde). Nursing has been changing since its institution, influenced by social, political and economic changes that seek, among other principles, humanization and comprehensiveness in health care. As a result of the struggles of the Sanitary Reform Movement, promulgation of the current Federal Constitution and implementation of SUS, the techno-health care model incorporated the expansion of the concept of health, requiring training schools of health professionals to reformulate their pedagogical projects ${ }^{(1)}$.

With regard to technical training, since the 1970 s, educational reforms have taken place in health education, with the aim of increasing the education of health workers ${ }^{(2)}$. In the 80 's, based on an agreement between the Ministry of Health, the Ministry of Social Security and the Ministry of Education, instituted by the Ordinance of March 11, 1980, as amended by the Ministerial Ordinance of April 27, 1984, ratified by the Resolution of the Comissão Interministerial de Planejamento e Coordenação (CIPLAN - Interministerial Commission for Planning and Coordination) 15 of November 11, 1985, the project known as the Large Scale Project (Projeto Larg Escala) ${ }^{(3)}$. This project had the objective of promoting and improving training of elementary and secondary level workers, associating supplementary education with in-service training, being carried out by some health organizations. The idealizer was the nurse Izabel dos Santos, also collaborator of the Pan American Health Organization (PAHO). At the time, it was estimated, in Brazil, that there were approximately 300 thousand workers working in health services, without specific qualification, performing various functions, including direct assistance to users of health facilities. In 2000, based on technical cooperation between the United Nations Educational, Scientific and Cultural Organization (UNESCO), the Ministry of Health, the Inter-American Development Bank (IDB), the National Treasury and the Fundo de Amparo ao Trabalhador (FAT - freely translated as Workers'Assistance Fund), the Profissionalização dos Trabalhadores da Área de Enfermagem (PROFAE - Professional Qualification Project of Workers) was created. This joint action enabled the mobilization of individuals and training institutions to develop a critical reference for changes and strengthening of SUS ${ }^{(3)}$. The PROFAE was created and directed to the workers from health services that carried out their own nursing actions, without professional technical qualification for the exercise of these actions. It was also directed at an expressive number of workers in the nursing activities, with no basic schooling, which caused impairment in the quality of health services offered to the population, implying a situation of irregularity and illegality of these people in the labor market ${ }^{(4)}$. In Brazil, PROFAE trained, from 2000 to 2006, 13,161 nurses specialized in Professional Education in Health, in the professional qualification courses that, at the time, were lato sensu postgraduate courses, called Specialization in Pedagogical Training in Professional Education in Health. The total workload was 660 hours. The requirements for enrollment were: to be a graduate in Nursing, to be a teacher of the Professionalization Program for Nursing Workers/PROFAE and be indicated by the Project. The objective was to offer specialization, so that the teacher, after graduating, was a multiplier of this process in schools $^{(5)}$. In the 1980s, when SUS was created in 1988, there was a movement of reorientation of strategies and models of care to achieve individual and collective health, seeking to change the formation and development in health, through several programs. Health Technical Schools then started to be called ETSUS (Escola Técnica em Saúde do Sistema Único de Saúde), and RETSUS (Rede de Escolas Técnicas o Sistema Único de Saúde), officially in 2000, articulating political and technical relations experienced to strengthen and integrate the network.

A Technical Training School, setting of this study, is part of RETSUS and, according to Decree 5154/04, Opinion 39/04 CNE (Brazilian Education Board)/CEB (Basic Education Chamber) and Deliberation 295/2005 of CEE-RJ, review and rework its PoliticalPedagogical Project ${ }^{(6-7)}$. The school's Political-Pedagogical Project (PPP) has as a mission:"to develop professional health education to consolidate the Brazilian Unified Health System, aiming to contribute to the quality of life of the population". The document highlights as ethical-political foundations: transformative practices, giving a new meaning to the concept of inclusion, taking into account the human competence to care for, valuing workers' autonomy, their everyday knowledge and experiences, and their capacity to transform work and life situation. It punctuates Problematic Education as a characteristic of the school and the active participation of learners in teaching-learning ${ }^{(8)}$. This methodology used in a Technical Training School is considered an active methodology by using teaching-learning strategies based on reality, for the training of instructors, professionals already working in health services and students. The problematization methodology allows us to observe reality (problem), to highlight what is relevant, to theorize the problem, to confront reality with its theorization, to formulate solution hypotheses by applying reality in practice ${ }^{(9-10)}$. The active method of critical and reflexive learning, supported by the Brazilian educational legislation and teacher training, sought to break with the traditional model, seeking the training of an emancipated professional in relation to teaching-learning, being prepared to meet the demands of the different settings of SUS ${ }^{(11)}$.

In 2007, a Technical School began to carry out the on-site Pedagogical Training, now called the Pedagogical Workshop, lasting 40 hours, being linked to the State Health Department of the State of Rio de Janeiro (SES-RJ - Secretaria Estadual de Saúde do Estado do Rio de Janeiro). The School Regiment and the Course Projects were authorized by Opinion 150/90 of the State Board of Education, established by the Ministerial Order 1298 of November 28, 2000, in order to comply with SUS principles to promote and carry out courses ${ }^{(12-13)}$. Implementation of the courses, in a decentralized way, was justified due to the needs of the municipalities and the technical conditions of the place. This performance made access of workers to qualification or training easier, avoiding displacement to places distant from work and, consequently, reducing the length of service. This training is an important tool for understanding work, with a perspective of a collective construction of knowledge and strategies for a comprehensive health care with quality, promoting integration 
between teaching-service and community. However, since 2008, the school has suffered an unprecedented precariousness, which began with a lack of autonomy to manage resources and hire a financial manager who managed the funds from the Ministry of Health for the implementation and implementation of courses, affecting the whole dynamics of the school and work. Currently, workshops for pedagogical training that until then were composed of five meetings lasting 8 hours each, totaling 40 hours depend on the availability of human and material resources of the municipalities. These changes not only interfered in the potential of creativity and commitment of teachers with pedagogical training for SUS, but also led to changes in pedagogical workshops, professional practice of teachers, favoring intra and extra institutional conflicts and difficulties in communication and interpersonal relationships.

Furthermore, this article seeks to make an approximation of experiences of teachers in Technical Schools based on collective analyzes of their practices in pedagogical training and in their work, from the following questioning: In what way has the pedagogical training been taking place in Technical Schools? Although this study brings the results of pedagogical training in only one setting, the political and social context that affected this Technical School in the 2000s may have had similar repercussions in other technical schools, which justifies a study that brings pedagogical training to debates in an adverse period in education and health policies ${ }^{(14)}$.

\section{OBJECTIVE}

This study aims to analyze the pedagogical training from teaching implications in a Technical School of SUS. This proposition seeks to approximate the experiences of teachers with pedagogical training comprised between 2008 and 2018, which were crossed by political changes in institutional health and education, interfering with work, pedagogical training and qualification of professionals for SUS.

\section{METHOD}

\section{Ethical aspects}

This project was submitted to and approved by the Research Ethics Committee of the University Hospital. In order to guarantee anonymity, the teachers' statements were identified by the letter T followed by a sequential number (T1 to T7).

\section{Type of study}

This is an intervention research with a qualitative approach, outlined by the theoretical and methodological framework of the Institutional Analysis, Institutional Socio-Clinical modality(15-16). The researcher maintains direct contact with people and with the context, making possible to modify by the experience produced by the intervention, being related as the researcher is implied with and in the research ${ }^{(15,17)}$. It is up to the researcher, during intervention, to think of a device that is the most effective to make the different institutions present speak, allowing to analyze collectively a collective situation $^{(18)}$. The Institutional Socio-Clinical intervention seeks to understand the social dynamics, bringing discussions as close as possible to the situations lived by participants, analyzing their implications with the institutions that cross them ${ }^{(15)}$. During the Institutional Socio-Clinical intervention, different moments can be experienced, where the eight characteristics proposed by Gilles Monceau can be evidenced, but not constituting in steps to be followed. The Institutional Socio-Clinical characteristics proposed by Monceau are:

Analysis of the order and demands; Participation of subjects in the devices; Work of analyzers; Analysis of transformations as work progresses; Application of refund arrangements; Work of primary and secondary implications; Intention of the production of knowledge; Attention to contexts and institutional interference $\mathrm{e}^{(15,19)}$.

\section{Methodological procedures for data collection}

This study included 7 health professionals, including only those who worked as teachers at the school, with employment and who were present during the period of data collection. The data were collected from a script with 05 questions. In this article, we will stick to the introduction. The devices used were: a diary of the researcher to analyze its implications and meetings in the framework of the Institutional Socio-Clinical intervention. The device is a type of assembly of heterogeneous elements, created for specific situations, constituting an intervention operator ${ }^{(20-22)}$. Regarding the diary, it was used as a writing device capable of leading the researcher to carry out the analysis of their belongings and their implications with the pedagogical training ${ }^{(23-24)}$. It is important to consider the attitude of the researcher, his implications for the problem and, especially, his role as a participant in every context in which the research is developed. The conduction of intervention meets the demands put by the group itself, and in this way, aspects related to the study are placed in the debates ${ }^{(25)}$.

Meetings were held between April 2017 and March 2018, the first three of which contemplated the preparation of the context for the research, when the Technical School's management presented the methodology, the objectives, the approval by the REC (Research Ethics Committee) and the individual invitations to participants. The fourth meeting took place with the group of teachers, according to the Institutional Socio-Clinical intervention, where the pedagogical training in the Technical School was debated. The fifth meeting was the moment of restitution, which is not only a devolution for the participants' lecture, but it is a methodological element to be considered in Socio-Clinical work. In the restitution, partial results of the research can be presented, allowing participants to remain active in intervention, giving opportunity to deepen or question the analyzes or even consider the orientation of the working device itself $f^{(15,19)}$.

\section{Study setting}

This study was developed in a Technical School of the Brazilian Unified Health System, which is a public institution linked to the network of SUS's Technical Schools, located in the state of Rio de Janeiro. 


\section{Data production}

The transcribed speeches, as well as the content of the researcher's diary, went through different readings, where it was sought to evidence the characteristics of Institutional Socio-Clinical. In this exercise, it was found that the same speech can be included in more than one characteristic because it is understood that in this methodological proposal the characteristics intertwine and merge during intervention, being able to be perceived in different phases of the intervention. They are part of an analytical work that is put into reflection by participants and researcher ${ }^{(15)}$. In the case of an intervention research, the data were produced by the different devices and research strategies that by collectively problematizing a given fact provided a more critical and reflexive positioning of participants ${ }^{(17)}$.

In response to the questioning, analysis of the testimonies and reports of the diary were manifested more clearly in two themes: implications of teachers with training: the old Technical School; New directions are evidenced in the implied behavior of teachers: a new Technical School?

\section{RESULTS}

Before presenting the results, it is important to know the participants of the study. All were female teachers, ranging in age from 44 to 64, with four nurses, a social worker, a biologist and a sociologist. With regard to qualification, two have Master's degree, three are studying Professional Master's degree, one is studying Doctorate and one is a Specialist. Working time at the Technical School ranged from two years to thirty years.

\section{1- Implications of tea,chers with training: the old Techni- cal School}

During intervention in collective debates, it was possible to identify different implications related to work in the Technical School and to pedagogical training. Teachers who started their activities before 2008 had the perception that the changes that occurred after 2008 caused a "dismantling" in the Technical School, resulting from other forms of relationship of professionals with higher organs in the offer of courses for pedagogical training, lack of autonomy in the management of financial resources, political interference with education and health, with repercussions on the pedagogical training for SUS.

With regard to the changes that led to the dismantling of the Technical School, they refer that:

From 2008 to the present time, the school has suffered a major dismantling. In fact, so our work has been permeated with a lot of resistance, a lot of resilience and also a lot of pain, is not it? Cause this has sickened us all. (T6)

We all go through sadness, frustration of knowing our potential, of seeing the potential that this school has already executed in the state of Rio de Janeiro. Now, it's been 10 years since I joined this school with a struggle for survival and this demands of us many strategies because institutionally we are very fragile. (T5)

All the management ... they have fought and they have fought, in order to make this school work in some way, but we do not find legal framework and political will to make it happen. (T7)
It was possible to perceive the difficulty of some teachers in experiencing changes in the physical, financial and personal structure and, mainly, how professional training courses were carried out. The feelings were of loss, the feeling that they were not working the way they were trained, the words that occurred the most during the first encounter were: struggle, resilience and resistance.

Regarding courses funding, participants revealed that changes caused the loss of the autonomy to manage the resources for their execution and implantation. This negatively affected all the dynamics of the school due to the difficulties of negotiating with the management about the courses to be offered and the lack of transparency regarding the allocation of resources, as reported below:

The school had a financial recourse that was deposited in the state health fund since 2007. I do not know where it was I do not know if it's still there, until the last time anyone knew. (T1)

This was the intention of the transfer, co-management ... this process happens like this: the municipality does a project with some manager of the health department, which has regional articulators. Create a project, then the money goes directly to this place of the municipality. But the school does not participate in this process. (T4)

... Because we alsodo not have budget allocation. We have no resources. So we need to work where our hands reach. We lectured courses, anyway, right? So, as far as we could go, we kept working. (T5)

It should be noted that with the decentralization of resources to the municipalities, another way of teaching was related to the Ministry of Health and the State Health Department. Negotiations began to be held with the Municipal Health Department which brought its own demands for courses and also other ways of relating to the Technical School. These changes were perceived negatively by some teachers.

The follow-up of the debates brings up the question of the pedagogical teacher training, where political interference with Education and also in implied positions of older patients are very visible:

Come on, pedagogical training. When I entered school in 2004, it was already this 40-hour scheme that, at the time, until about 2007 , I think, something like that. No, until 2008 ... I participated. I joined in 2008; I participated in several the whole week. (T1)

Well, it was already the 40-hour scheme, a whole week. It started from 8 a.m., 9 a.m. and went until 5 p.m. Only at the time, I was as secretary of the board, and I had no release to stay all this time outside the office... When I had time to participate, then the training no longer happened. (T2)

Before this dismantled the School was decentralized, had other schools. So, people kept giving... carrying out pedagogical training in other municipalities. They did not necessarily stay in the school ... Now it's so fast, right? (T1)

Teachers understood as losses the fact that training was no longer conducted in 40 hours and also in relation to being taught in other spaces, which determined when they would be performed, in which place and their workload. 
By being placed in debates as participants perceived themselves as teachers before 2008 and in the present moment, they reveal the suffering expressed by the failures facing the reality at work, collaborating with the institutional, professional and personal emptiness. The testimonies reveal these feelings:

I feel very, very excluded. But it's what ... Excluded in pairs. Because there are certain meetings that are... Me and you, you and me. And I did not start in nursing now, I started in nursing a long time ago. (T2)

But it is already so, but what I realize is that everyone is becoming discouraged ... Because it is history of struggle. (T3)

The researcher's diary complements the situation brought by participants:

I was very anxious and apprehensive about the meeting. I was expecting a bit of confusion or disagreement. But we find professionals extremely involved with work, crossed by several institutions. During the meetings, they expressed diverse feelings such as exclusion, lack of belonging, much suffering with the processes of what they called the dismantling of Technical School. I was very affected and impacted by the reports, mainly because I did not perceive the feelings of the colleagues in these years of work...

The statements allowed to identify issues that were not previously verbalized and that, when they were put into collective debates, made it possible to analyze the implications of teachers with "dismantling" of the Technical School and, above all, with pedagogical training.

\section{2- New directions are evidenced in the implied behavior of teachers: a new Technical School?}

Starting from the assumption that everything is in constant movement, the transformations that occurred throughout intervention, could be perceived in the meeting of restitution, when teachers, carrying out an analysis of their implications with pedagogical training, began to have another understanding about work and problematization:

The school's methodology is hard because you have to respect the other and the knowledge of the other and listen to the other. Build what he has from what he has. This is hard. For those who are used to a traditional methodology, get on the board and such, it does not fit at all ... we know that you need to be studying because there are other methodologies other than ours, maybe even more effective than ours. We know you have several other methodologies... And then I think we need to appropriate these other methodologies, although our ... [...] it is not a straightjacket, right? Not a straitjacket. (T1)

This different way of perceiving reality began to reveal a new Technical School where participants sought alternatives to continue working and develop their training as teachers, bringing other experiences in this training. It was interesting to analyze the implications of older teachers still attached to the norms and rules of the institution of pedagogical training before 2008 , and teachers who had another perception regarding these changes.
In this space of collective debates, all participants could perceive these two movements: more established and crystallized positions in the practice of some participants; and positions that sought strategies in that context, in more institutional movements. The testimonies of new teachers after 2008, and even of some older ones, surprised by the diversity of activities related to pedagogical training and personal qualification, as can be seen below:

I'm going to Brasilia, we're taking part in a specialization course that ends this month. The demand arrived for SES/RJ, the director gave the endorsement and I went to make the qualification of the instructors in Cambuci-RJ. I also qualified instructors for the Introductory Course for Endemics Community Agent. Everything worked out. (T3)

Those who brought a proposal of work, the proposals were not rejected. Who wanted to do specialization, did it. Whoever wanted to do Master's Degree course, did it. Everyone who wanted to study since 2009, has been released. So people did not stand still... (T5)

Activities of production of didactic material used in the training of SUS workers, besides several training courses:

The school coordinated some demands from the Ministry of Health itself with two letters of agreement of the Ministry of Health with PAHO to produce guidelines and didactic material for two technical courses: Technician in Psychopathology, Technician in Orthosis and Prosthesis. He also coordinated two major projects for the Ministry of Health. Care Pathways [Caminhos do Cuidado] that in 2015 and 2016 helped more than 16 thousand people in more than 75 municipalities here in the State. And I currently coordinate, in the school, the Itineraries of Knowledge Project [Projeto Itinerários do Saber], which is the continuation of the Care Pathways. (T5)

With regard to the researcher, the changes in teachers' attitude were well portrayed in her diary, on the restitution meeting:

Initially, only three people had confirmed their presence. On the day to my surprise, three more people attended. Four teachers exchanged the work day and time to participate. I consider this moment very important, because we have difficulties to gather people in the school, and the team appeared in a spontaneous and joyful way. It was a pleasant surprise.

These reports reveal new positions of the researcher and of participants and it was verified that the collective reflections carried out during the interventions according to the Institutional Socio-Clinical made possible self-knowledge, perception of the suffering of the other, a rethinking about work and pedagogical training when analyzing its affective, personal and ideological implications.

\section{DISCUSSION}

In this article, there were references to health, education and pedagogical training institutions. The concept of an institution is polysemous, and it is not possible to conceive it as a social formation, but rather as the intertwining of different instances, such as economic, political and ideological(18,21). 
Every institution has three moments: universality, particularity and singularity ${ }^{(18)}$. In the reports, it was possible to identify the moment of universality, when teachers made reflections regarding the losses of their old practices before 2008, which correspond to what had been established in its rules, norms values, in pedagogical training. The second moment, particularity, could be perceived when teachers began to reflect on their new role as teachers and in the strategies sought in training, producing conditions of action of instituting forces ${ }^{(26)}$. These refer to the set of material and social determinations that deny the first moment. Finally, the third moment, singularity, resulting from the negation of the old institutional norms and the acceptance by all or only by some of them of new rules, norms and ideologies that remain in constant movement in search of reaching a certain objective, leading to a new institutionalization ${ }^{(18)}$.

The results point to the nuances of a permanent institutionalization of pedagogical training. This new institution appears permeated by disputes between the instituted forces and the instituting ${ }^{(27)}$. In the case of this research, they are still charged with feelings of recognition of the other, of individual differences and of possibilities of expanding interpersonal relations. The institution finds itself somewhere among the revolutionary forces of the institute and those more conservative of the instituted. In this struggle, institutionalization seeks the instituted, its forms more stable and, at the same time, seeks to break from instituting forces, this permanence, from innovative changes, this movement is continually sustained by dialectical forces that remain permanently permeable, fluid and elastic ${ }^{(18,26,28)}$.

With regard to professional involvement, this arose with the institutionalists, in denying scientific neutrality in their interventions, since they understood that every researcher is emotionally and professionally involved with its object ${ }^{(20,29)}$. The professional implication is the set of relations that the subject establishes with the profession (thought like institution with its own dynamics) to which it belongs, and with the other institutions in which, or in connection with which, he exercises his profession, and this according to the libidinal, professional and ideological dimensions. As for professional practice, it consists of the set of professional implications of a subject, including ways of relating to the other members of the profession (and, or with other institutions involved in the profession) to think about those relations and to give them meaning and values ${ }^{(15,19)}$. This concept makes sense, when, in the testimonies, personal implications can be perceived when referring to the suffering caused by "dismantling"; professional implications, when they emphasize the need to have a lot of resistance, resilience and struggle to keep the Technical School in operation; and ideological implications, when referring as health and education institutions interfere with their work as trainers for SUS. It could be said that the professional teaching practice of this study was constituted through the set of professional implications of all participants, including ways to relate to co-workers, other institutions, to think about relationships and to assign them some meaning and value. Through this daily and reflexive contact, "as in a mirror - the professional recognizes himself by looking and being with the other, at the same time that he is also forming from the other"(22).

It can be seen in the testimonies how the Technical School appears crossed by education and health institutions and how the political interferences lead each participant to have a kind of implication with these institutions and with the institutions that cross them.
The discourses reveal that the decentralization of power, the lack of pedagogical and financial autonomy of the school, provoke conflicting situations at work, interfering with the professional and personal life of participants. Some Technical Schools experience bureaucratic obstacles and are influenced by local political issues, in a negative way, in this process, since the majority do not have administrative, financial and decision-making autonomy, increasing the precariousness of the formation and the qualification of the workers ${ }^{(30-31)}$. They also point out that the lack of autonomy of some technical schools for the management and execution of resources does not contribute to the changes that are necessary and increases the precariousness of training and qualification of workers ${ }^{(1,30)}$.

With regard to the implications of participants with the use of the methodologies of the problem, different studies about training in technical schools, point this methodology as teaching, learning and evaluation strategy in the active methodology, by anchoring itself in the pedagogical conception that encourages the student's participation, developing autonomy and understanding of individual and collective responsibility in learning ${ }^{(30-31)}$. They point out that the difficulties in the pedagogical dimension refer to the turnover of professionals, the lack of mastery in the application of the methodology, the lack of didactic material and often to the lack of financial resources to make feasible the projects similar to the results of this study ${ }^{(11,30-31)}$.

The specificity of this study is the way in which professionals experienced the "dismantling" in Technical Schools and how they looked for strategies to continue training even in a context permeated by conflicts and by political and institutional interferences in Health and Education. The study revealed that participants were able to leave their established spaces to seek and experience new instituting experiences in pedagogical training, such as the search for stricto and lato sensu post-graduation courses; offer of courses using platforms from the Ministry of Health; production of didactic material; participation in different professional qualification projects for SUS, among others. These actions have led to reflections that pedagogical training can be thought of in a much more comprehensive way, besides the space of the Technical School.

The main result of this study was the ability of teachers to understand their ability to act through a better understanding of the emotional, professional and ideological dimensions inherent in any practice based on the analysis of their implications ${ }^{(32)}$. Accepting and analyzing these dimensions can contribute to give more power and legitimacy to the teaching work, building a space for dialogue and reflective analysis with the institutions that pass through us, which can bring benefits to the pedagogical training of the Technical School ${ }^{(32)}$. A process of training understood as the constitution of subjects, lived in an interactive process and, therefore, intersubjective, where the senses were given a new meaning by all participants, mainly by the researcher, confirming that from the dialogue and the unveiling of previously unacknowledged situations that caused suffering in all, one can face the condition of heterogeneity of the daily life of the pedagogical teacher training ${ }^{(2)}$.

The devices used to analyze professional practices in pedagogical training and the use of the methodological proposal of the Institutional Socio-Clinical allowed the analysis of the participants implications, bringing them closer to their weaknesses and potentialities, allowing them to strengthen as a group. 


\section{Study limitations}

It is highlighted as a limitation of the study, the fact that the results highlight pedagogical teacher training in only one reality. Similar studies using this methodological proposal would be interesting in the sense of knowing how other teachers experienced the pedagogical training in adverse contexts.

\section{Contributions to the fields of Nursing, Health or Public Policy}

This study contributed to the debate and reflections on pedagogical training of a Technical School teachers and professional quality training for SUS.

\section{FINAL CONSIDERATIONS}

This study made it possible to know the factors that hinder and facilitate pedagogical training; to identify how teachers perceive themselves in training; and mainly to clarify how the established behaviors opened loopholes for instituting movements present in that setting, revealing the nuances of a new institutionalization. It has contributed, above all, to the collective construction of strategies related to the training of professionals, aiming at improving the quality of education offered to workers and society.

The use of the Institutional Analysis and, specifically, Institutional Socio-Clinical methodology, produced deep reflections in the group of school teachers, making them rethink their own pedagogical practices and work, giving a new meaning to these processes and challenging them to overcome.

Reflections brought by this research demonstrate the relevance of future research in this field, since it can serve as a theoretical and methodological contribution in other areas, in order to ratify the impressions recorded here. New studies are recommended in order to contribute to the pedagogical training of new teachers and the strengthening of SUS.

\section{REFERENCES}

1. Leite ICM, Mourão LC, Almeida ACV. Pedagogical training of the technical schools of the Unified Health System. Rev Enferm UFPE. 2018;12(3):781-9. doi: 10.5205/1981-8963-v12i3a23561p781-789-2018

2. Cunha RCOB, Ometto CBCN, Prado GVT. Trabalho docente coletivo e coordenação pedagógica: entre a heterogeneidade do cotidiano e um projeto de formação de professores. Rev Educ PUC-Camp [Internet]. 2013 [cited 2016 Aug 31];18(2):171-9. Available from: http:// periodicos.puc-campinas.edu.br/seer/index.php/reveducacao/article/view/2026

3. Ministério da Saúde (BR). Resolução C1PLAN n¹5, de 11 de novembro de 1985. Dispõe sobre a aprovação do Projeto de Formação em Larga Escala de Pessoal de Nível Médio. Brasília: Ministério da Saúde; 1985.

4. Pereira IB, Ramos MN. Educação Profissional em Saúde. Fiocruz: Rio de Janeiro, 2006.

5. Nunes TCM. A história, a saúde pública e a cooperação técnica: antigos nexos e novos desafios do mundo globalizado. Ciênc Saúde Colet. 2008;13(3):830-9. doi: 10.1590/S1413-81232008000300005

6. Conselho Estadual de Educação (CEE). Deliberação CEE № 295/2005. Estabelece normas para o credenciamento de Instituições e autorização de cursos de Educação Profissional Técnica de Nível Médio para o Sistema Estadual de Ensino do Rio de Janeiro [Internet]. Rio de Janeiro CEE; 2006 [cited 2016 Aug 31]. Available from: http://www.cee.rj.gov.br/deliberacoes/D_2005-295.pdf

7. Ministério da Saúde (BR). Portaria GM/MS n 198, de 13 de fevereiro de 2004. Institui a Política Nacional de Educação Permanente em Saúde [Internet]. Brasília: Ministério da Saúde; 2009 [cited 2015 Dec 01]. Available from: http://bvsms.saude.gov.br/bvs/publicacoes/politica nacional_educacao_permanente_saude.pdf

8. Escola de Formação Técnica em Saúde Enfermeira Izabel dos Santos (ETIS). Projeto Político Pedagógico. Rio de Janeiro: ETIS; 2008

9. Luckesi CC. Avaliação da Aprendizagem Escolar: estudos e proposições. 22a ed. São Paulo: Cortez; 2011.

10. Bordenave JD, Pereira AM. Estratégias de Ensino-Aprendizagem. 22ª ed. Petrópolis: Vozes; 2001.

11. Camargo RAA, Coloni CSM, Teixeira VM, Moreira MCO, Piotto R, Góes FDSN. Prática Pedagógica na Educação Profissional de Nível Médio em Enfermagem. Cogitare Enferm [Internet]. 2016 [cited 2018 Aug 31]; 21(1):1-9. Available from: http://revistas.ufpr.br/cogitare/article/view/42026

12. Paraná (Estado). Conselho Estadual de Educação (CEE). Parecer $n^{\circ} 150 / 17$, pedido de renovação do reconhecimento do Ensino Médio [Internet]. Paraná: CEE; 2017 [cited 2018 Aug 31]. Available from: http://www.cee.pr.gov.br/modules/conteudo/conteudo.php?conteudo=585

13. Ministério da Saúde (BR). Portaria no 1298/GM, de 28 de novembro de 2000. Instituir a Rede de Escolas Técnicas e Centros Formadores vinculados às instâncias gestoras do Sistema Único de Saúde (RET-SUS) (Revogada pela Portaria n 1168 de 08/07/2005) [Internet]. Brasília: Ministério da Saúde; 2000 [cited 2016 Aug 31]. Available from: http://10.1.1.213/portal/arquivos/pdf/portaria\%201298-2000.pdf

14. Correa AK, Sordi MRL. The secondary technical-professional education in the sus and the teacher training policy. Texto Contexto Enferm. 2018;27(1):e2100016. doi: 10.1590/0104-07072018002100016

15. Monceau G. Técnicas socioclínicas para a análise institucional das práticas sociais. Psicol Rev. 2015;21(1):197-217. doi: 10.5752/P.1678-9523.2015V21N1P197

16. Minayo MCS. O desafio do conhecimento: pesquisa qualitativa em saúde. São Paulo: Hucitec; 2014.

17. Mendes R, Pezzato LM, Sacardo DP. Research and intervention in the promotion of health: methodological challenges of researching "with". Ciênc Saúde Colet. 2016;21(6):1737-46. doi: 10.1590/1413-81232015216.07392016. 
18. Lourau R. A Análise Institucional. 4ª ed. Rio de Janeiro: Vozes; 2014.

19. Monceau G. Le courrier électronique dans les pratiques professionnelles. En éducation, santé et action sociale: usages et effets. Paris: Champ Social Éditions; 2013.

20. Rossi A, Passos E. Análise Institucional: revisão conceitual e nuances da pesquisa-intervenção no Brasil. Rev EPOS[Internet]. 2014 [cited 206 Aug 31];5(1):156-81. Available from: http://pepsic.bvsalud.org/scielo.php?script=sci_arttext\&pid=S2178-700X2014000100009

21. Spagnol CA, L'Abbate S, Monceau G, Jovic L. Dispositif socianalytique: instrument d'intervention et de collecte de données en recherche qualitative en soins infirmiers. Rech Soins Infirm. [Internet]. 2016 [cited 2018 Aug 14];1(124):108-17. Available from: https://www.cairn.info/ revue-recherche-en-soins-infirmiers-2016-1-page-108.htm

22. Borges FA, Rézio LA, L'Abbate S, Fortuna CM. The entry in the field and the creation of devices in socioclinical research. Psicol Estud. 2018;23:e40373. doi: 10.4025/psicolestud.v23.e40373

23. Hess R. Momento do diário e diário dos momentos. In: Souza EC, Abrahão MHMB, organizadores. Tempos, narrativas e ficções: a invenção de si. Porto Alegre: EDIPUCRS; 2006. p. 89-103.

24. Jesus AF, Pezzato LM, Abrahão AL. O uso do diário como ferramenta estratégica da análise institucional para abordar o cotidiano do profissional de saúde. O caso do Dom Queixote. In: L’Abbate S, Mourão LC, Pezzato LM, organizadores. Análise Institucional \& Saúde Coletiva. São Paulo: Hucitec; 2013. p. 206-39.

25. Pezzato LM, Prado GVT. Pesquisa-ação e pesquisa intervenção: aproximações, distanciamentos, conjugações. In: L'Abbate S, Mourão LC, Pezzato LM, organizadores. Análise Institucional \& Saúde Coletiva. São Paulo: Hucitec; 2013. p. 149-79.

26. Romagnoli, R. O conceito de implicação e a pesquisa-intervenção institucionalista. Psicol Soc. 2014;26(1):44-52. doi: 10.1590/ S0102-71822014000100006

27. Fortuna CM, Silva SS, Mesquita LP, Matumoto S, Oliveira PS, Santana FR. The institutional socio-clinic as a theoretical and methodological framework for nursing and health research. Texto Contexto Enferm. 2017;26(4):e2950017. doi: 10.1590/0104-07072017002950017

28. Baremblitt G. Compêndio de Análise Institucional. 5ª ed. Belo Horizonte: Instituto Félix Guattari; 2012.

29. Lourau R. Implicação e sobreimplicação. In Altoé S, organizadora. René Lourau: analista institucional em tempo integral. São Paulo: Hucitec; 2004. p. $186-98$

30. Galvão EDA, Sousa MFD. As escolas técnicas do SUS: que projetos político-pedagógicos as sustentam? Physis. 2012;22(2):1159-89. doi: 10.1590/S0103-73312012000300017

31. Gottems LBD, Alvarez AM, Almeida LMWS. Nursing education: quality, innovation and accountability. Rev Bras Enferm. 2014;67(4):499-500. doi: 10.1590/0034-7167.2014670401

32. Mourão LC, Soussume T. Réflexions sur les actions du programme HIPERDIA dans les centres de santé: implications des professionnels. Diversitates [Internet]. 2015 [cited 2017 Mar 20];7(2):34-43. Available from: http://www.diversitates.uff.br/index.php/1diversitates-uff1/ article/view/103/77 